\title{
Polymorphisms in TIM-3 and breast cancer susceptibility in Chinese women: A case-control study
}

\author{
Zheng Wang ${ }^{1,2}$, Xinghan Liu ${ }^{1}$, Xijing Wang ${ }^{1}$, Tie Chong ${ }^{3}$, Shuai Lin ${ }^{1}$, Meng Wang ${ }^{1}$, \\ Xiaobin Ma ${ }^{1}$, Kang Liu ${ }^{1}$, Peng $\mathrm{Xu}^{1}$, Yanjing Feng ${ }^{1}$, Zhijun Dai ${ }^{1}$ \\ ${ }^{1}$ Department of Oncology, Second Affiliated Hospital of Xi'an Jiaotong University, Xi'an 710004, China \\ ${ }^{2}$ Department of Medical Oncology, Xi'an Central Hospital, Xi'an 710004, China \\ ${ }^{3}$ Department of Urologic Surgery, Second Affiliated Hospital of Xi'an Jiaotong University, Xi'an 710004, China \\ Correspondence to: Zhijun Dai, email: dzj0911@126.com; dzj0911@mail.xjtu.edu.cn \\ Keywords: TIM-3, breast cancer, polymorphism, case-control study \\ Received: December 22, $2015 \quad$ Accepted: May 12, $2016 \quad$ Published: May 27, 2016
}

\section{ABSTRACT}

Previous studies have found associations between polymorphisms in $T$ cell immunoglobulin and mucin domain 3 (TIM-3) and increased risks of various cancers. However, the association between TIM-3 polymorphisms and breast cancer (BC) remains uncertain. In this study, a total of 560 BC patients and 583 age, sex, and ethnicity-matched healthy controls from Northwest China were included. The polymorphisms were genotyped using Sequenom MassARRAY. The expression level of TIM-3 protein was detected by immunohistochemistry. We observed rs10053538 had a significantly increased risk of $\mathrm{BC}$, comparing with the wild-type genotype even after Bonferroni correction. In addition, the rs4704853 G>A variants were more frequent among BC patients than the controls (GA + AA vs. GG: OR $=1.32,95 \% \mathrm{CI}=1.03-$ $1.69, P=0.026)$; However, the significance was lost after Bonferroni correction ( $P=$ 0.078). Furthermore, rs10053538 was associated with lymph node metastasis. Age stratification revealed that among patients aged $<49$ years, those with the rs 4704853 GA/AA genotype had a higher risk of BC; But there was no difference when Bonferroni correction was conducted. Immunohistochemical analysis showed that the expression of TIM-3 protein in the breast cancer tissues was higher in patients carrying the rs10053538 GT+TT genotype than those with GG genotype $(P=0.012)$. However, we failed to find any difference between BC patients and controls in any rs1036199 genetic model. These findings suggested that rs10053538 in TIM-3 might increase susceptibility to BC and promote the progression of BC in Chinese women.

\section{INTRODUCTION}

Cancer is one of the four leading causes of morbidity and mortality worldwide, with a high incidence in developing countries [1]. Breast cancer (BC) is the most common malignancy affecting women, with 1.8 million newly diagnosed cases in 2013, and is the leading contributor to disability-adjusted life-years [2-4]. The incidence of $\mathrm{BC}$ is increasing worldwide, as is the effect of hereditary BC. In Iceland, the number of carriers of mutations in the gene encoding breast cancer 2 (BRCA2) who are younger than 70 years was estimated to have increased fourfold (from $18.6 \%$ to $71.9 \%$ ) over the last century, whereas the cumulative incidence of non-carriers also increased fourfold (from $2.6 \%$ to $10.7 \%$ ) during the same period [5]. Women who test positive for familial $B R C A 1 / B R C A 2$ mutations are likely to have a higher risk of developing $\mathrm{BC}[6,7]$. Additionally, other factors such as chemokines, microRNAs, and single nucleotide polymorphisms (SNPs) have been proven to associate with $\mathrm{BC}$ risks, progression, and metastasis [8-10].

Proteins within the T-cell immunoglobulin and mucin domain (TIM) family, which comprises three members (TIM-1, TIM-3 and TIM-4) encoded from genes on human chromosome $5 \mathrm{q} 33.2$, are expressed on $\mathrm{T}$ cells [11]. TIM-3, which negatively regulates $\mathrm{T}$ cell helper (Th1) cells and affects cytokine expression, has been associated with cancer susceptibility [12-14]. $T I M-3$, together with its ligand galectin- 9 , can induce $T$ cell proliferation, cytotoxicity, and apoptosis $[15,16]$. 
The primary involvement of TIM-3, as well as PD-1, in atherosclerosis, human immunodeficiency virus (HIV) infection, and regionally metastatic differentiated thyroid cancer contributes to exhaustion of $\mathrm{T}$ cells through pathways that regulate $\mathrm{CD}^{+} \mathrm{T}$ cells function [17-19].

To date, several lines of evidence have demonstrated associations of SNPs in TIM-3 with increased risks of osteoarthritis, non-Hodgkin lymphoma, and non-smallcell lung cancer [20-22]. However, few articles have investigated the rs10053538, rs4704853, and rs1036199 polymorphisms, and none have estimated the associations between these three TIM-3 SNPs and BC susceptibility. In this case-control study, we aimed to examine the associations of the TIM-3 rs10053538, rs4704853, and rs1036199 polymorphisms with the risk of BC in a Northwest Chinese population.

\section{RESULTS}

\section{Characteristics of the patients and controls}

The characteristics of the 560 patients with BC and 583 controls are presented in Table 1. No significant differences were noted between patients with $\mathrm{BC}$ and controls in the distributions of age $(P=0.612)$ and menopausal status $(P=0.716)$. However, patients with $B C$ and healthy controls differed significantly with respect to body mass index (BMI) $(\mathrm{P}=0.038)$. Therefore, statistical analysis based on case-control comparisons was adjusted for age and BMI. The cases consisted of 313 (55.89\%) estrogen receptor (ER) positive tumors, 305 (54.46\%) progesterone receptor (PR)-positive tumors, 171 (30.54\%) human epidermal growth factor receptor 2 (Her-2) positive tumors.

\section{Association between TIM-3 polymorphisms and breast cancer risk}

All three SNPs of TIM-3 gene were genotyped in $560 \mathrm{BC}$ patients and 583 healthy control subjects, but some cases and controls were missing. The genotyping success rates of rs10053538, rs4704853, and rs1036199 were 99.83\% (1141/1143), 99.56\% (1138/1143), and 99.74\% (1140/1143) respectively. The genotype and allelic frequencies of the TIM-3 rs10053538, rs4704853, and rs1036199 polymorphisms are shown in Table 2. In the controls, the genotype frequencies of all three SNPs conformed to Hardy-Weinberg Equilibrium (HWE) (P $=0.10,0.28$, and 0.74 for rs 10053538 , rs4704853, and rs1036199, respectively), indicating that community

Table 1: Distributions of select variables in breast cancer cases and cancer-free controls

\begin{tabular}{|c|c|c|c|c|}
\hline Characteristics & & Cases & Control & $P$ value* \\
\hline Number & & 560 & 583 & \\
\hline Age $($ mean \pm SD $)$ & & $49.09 \pm 11.02$ & $48.80 \pm 8.28$ & 0.612 \\
\hline \multicolumn{5}{|l|}{ Menopausal status } \\
\hline Premenopausal & & 264 & 281 & \\
\hline Postmenopausal & & 296 & 302 & 0.716 \\
\hline \multicolumn{5}{|c|}{ Body mass index $\left(\mathrm{kg} / \mathrm{m}^{2}\right)$} \\
\hline$($ mean $\pm \mathrm{SD})$ & & $22.52 \pm 2.84$ & $22.95 \pm 3.21$ & 0.038 \\
\hline \multirow[t]{2}{*}{ Tumor size } & $<2 \mathrm{~cm}$ & 188 & & \\
\hline & $\geq 2 \mathrm{~cm}$ & 372 & & \\
\hline \multirow[t]{2}{*}{ LN metastasis } & Negative & 236 & & \\
\hline & Positive & 324 & & \\
\hline \multirow[t]{2}{*}{ ER } & Negative & 247 & & \\
\hline & Positive & 313 & & \\
\hline \multirow[t]{2}{*}{ PR } & Negative & 255 & & \\
\hline & Positive & 305 & & \\
\hline \multirow[t]{2}{*}{ Her-2 } & Negative & 389 & & \\
\hline & Positive & 171 & & \\
\hline
\end{tabular}

*T-test or two-sided $x^{2}$-test.

LN, Axillary lymph node; ER, Estrogen receptor; PR, Progesterone receptor; HER-2, human epidermal growth factor receptor 2 
Table 2: Genotype and allele frequencies of the TIM-3 polymorphisms among the cases and controls and the associations with breast cancer risk

\begin{tabular}{|c|c|c|c|c|c|c|}
\hline Model & Genotype & Case(560) & Control(583) & OR $(95 \% \text { CI })^{\dagger}$ & P-value* & $\mathbf{P}_{\mathbf{c}}$ \\
\hline \multicolumn{7}{|l|}{$\mathrm{rs} 10053538^{\mathrm{a}}$} \\
\hline \multirow[t]{3}{*}{ Codominant } & GG & $173(30.9 \%)$ & $221(38.0 \%)$ & 1.00 (reference) & & \\
\hline & $\mathrm{GT}$ & $313(56.0 \%)$ & $290(49.8 \%)$ & $1.38(1.07-1.178)$ & 0.014 & 0.042 \\
\hline & TT & $73(13.1 \%)$ & $71(12.2 \%)$ & $1.31(0.90-1.93)$ & 0.162 & NS \\
\hline \multirow[t]{2}{*}{ Dominant } & GG & $173(30.9 \%)$ & $221(38.0 \%)$ & 1.00 (reference) & & \\
\hline & $\mathrm{GT}+\mathrm{TT}$ & $386(69.1 \%)$ & $361(62.0 \%)$ & $1.37(1.07-1.75)$ & 0.013 & 0.039 \\
\hline \multirow[t]{2}{*}{ Recessive } & GG-GT & $486(86.9 \%)$ & $511(87.8 \%)$ & 1.00 (reference) & & \\
\hline & TT & $73(13.1 \%)$ & $71(12.2 \%)$ & $1.08(0.76-1.53)$ & 0.662 & NS \\
\hline \multirow[t]{2}{*}{ Allele } & G & $659(58.9 \%)$ & $732(62.9 \%)$ & 1.00 (reference) & & \\
\hline & $\mathrm{T}$ & $459(41.1 \%)$ & $432(37.1 \%)$ & $1.18(0.997-1.40)$ & 0.054 & NS \\
\hline \multicolumn{7}{|l|}{ rs $4704853^{b}$} \\
\hline \multirow[t]{3}{*}{ Codominant } & $\mathrm{G} / \mathrm{G}$ & $352(63.1 \%)$ & $402(69.3 \%)$ & 1.00 (reference) & & \\
\hline & $\mathrm{G} / \mathrm{A}$ & $191(34.2 \%)$ & $166(28.6 \%)$ & $1.31(1.02-1.69)$ & 0.034 & NS \\
\hline & $\mathrm{A} / \mathrm{A}$ & $15(2.7 \%)$ & $12(2.1 \%)$ & $1.43(0.66-3.09)$ & 0.364 & NS \\
\hline \multirow[t]{2}{*}{ Dominant } & GG & $352(63.1 \%)$ & $402(69.3 \%)$ & 1.00 (reference) & & \\
\hline & $\mathrm{GA}+\mathrm{AA}$ & $206(36.9 \%)$ & $178(30.7 \%)$ & $1.32(1.03-1.69)$ & 0.026 & NS \\
\hline \multirow[t]{2}{*}{ Recessive } & GG-GA & $543(97.3 \%)$ & $568(97.9 \%)$ & 1.00 (reference) & & \\
\hline & $\mathrm{AA}$ & $15(2.7 \%)$ & $12(2.1 \%)$ & $1.31(0.61-2.82)$ & 0.493 & NS \\
\hline \multirow[t]{2}{*}{ Allele } & G & $895(80.2 \%)$ & $970(83.6 \%)$ & 1.00 (reference) & & \\
\hline & $\mathrm{A}$ & $221(19.8 \%)$ & $190(16.4 \%)$ & $1.26(1.02-1.56)$ & 0.034 & NS \\
\hline \multicolumn{7}{|l|}{ rs1036199c } \\
\hline \multirow[t]{3}{*}{ Codominant } & $\mathrm{A} / \mathrm{A}$ & $546(97.7 \%)$ & $565(97.2 \%)$ & 1.00 (reference) & & \\
\hline & $\mathrm{C} / \mathrm{A}$ & $13(2.3 \%)$ & $16(2.8 \%)$ & $0.84(0.40-1.76)$ & 0.646 & NS \\
\hline & $\mathrm{C} / \mathrm{C}$ & 0 & 0 & & & \\
\hline \multirow[t]{2}{*}{ Allele } & A & $1105(98.8 \%)$ & $1146(98.6 \%)$ & 1.00 (reference) & & \\
\hline & $\mathrm{C}$ & $13(1.2 \%)$ & $16(1.4 \%)$ & $0.84(0.40-1.76)$ & 0.648 & NS \\
\hline
\end{tabular}

*Two-sided $x^{2}$ test for the distributions of genotype and allele frequencies.

${ }^{\dagger}$ Adjusted for age and body mass index.

$\mathrm{P}_{\mathrm{c}}$, the Bonferroni correction of $\mathrm{P}$ values.

${ }^{\mathrm{a} C}$ ase missing $\mathrm{n}=1$; control missing $\mathrm{n}=1$;

${ }^{\mathrm{b}}$ Case missing $\mathrm{n}=2$; control missing $\mathrm{n}=3$;

${ }^{\mathrm{c}}$ Case missing $\mathrm{n}=1$; control missing $\mathrm{n}=2$.

genetic inheritance was balanced in the control samples and that these samples could represent the general population.

Of all selected TIM-3 SNPs, rs10053538 was identified as associated with the risk of BC. For rs10053538, we found that GT and GT + TT genotype carriers had a significantly increased risk of BC development (GT vs. GG: $\mathrm{OR}=1.38,95 \% \mathrm{CI}=1.07-1.78, \mathrm{P}=0.014, \mathrm{P}_{\mathrm{c}}=0.042$;
GT + TT vs. GG: OR $=1.37,95 \% \mathrm{CI}=1.07-1.75, \mathrm{P}=$ $\left.0.013, \mathrm{P}_{\mathrm{c}}=0.039\right)$ relative to those with the GG genotype. For rs4704853 polymorphism, the GA and GA + AA frequencies among patients differed significantly from the GG genotype observed among the controls (GA vs. GG: $\mathrm{OR}=1.31,95 \% \mathrm{CI}=1.02-1.69, \mathrm{P}=0.034 ; \mathrm{GA}+\mathrm{AA}$ vs. GG: $\mathrm{OR}=1.32,95 \% \mathrm{CI}=1.03-1.69, \mathrm{P}=0.026)$; However, after Bonferroni correction, the significance was lost (GA 
vs. GG: $P_{c}=0.102 ; G A+A A$ vs. GG: $\left.P_{c}=0.078\right)$. The differences in the $\mathrm{G}$ and $\mathrm{A}$ allele frequency distributions between patients and controls were also significant $(\mathrm{OR}=1.261,95 \% \mathrm{CI}=1.02-1.56, \mathrm{P}=0.034)$; But there was no significant difference when Bonferroni correction was performed $\left(\mathrm{P}_{\mathrm{c}}=0.102\right)$. We did not observe significant differences among the rs1036199 genotypes (CA vs. AA: $\mathrm{OR}=0.84,95 \% \mathrm{CI}=0.40-1.76, \mathrm{P}=0.646 ; \mathrm{C}$ vs. $\mathrm{A}: \mathrm{OR}$ $=0.84,95 \% \mathrm{CI}=0.40-1.76, \mathrm{P}=0.648)$. We also obtained the statistical power of 0.81 and 0.83 for the two significant polymorphisms identified, rs10053538 and rs4704853, respectively. This showed that our sample size of 1143 was adequate and the study was sufficient to detect the associations of these two polymorphisms with $\mathrm{BC}$ risk.

\section{Association between TIM-3 polymorphisms and clinical parameters in patients with breast cancer}

To investigate potential associations between TIM-3 polymorphisms and clinical features in patients with $\mathrm{BC}$, we next analyzed the associations between these polymorphisms and a series of clinicopathological parameters, including tumor size, lymph node (LN) metastasis, ER, PR, and Her-2 statuses. As shown in Table 3, we identified a significantly higher frequency of the rs10053538 polymorphism among patients with a positive LN metastasis status $(\mathrm{OR}=1.68,95 \% \mathrm{CI}=1.17$ $\left.2.42, \mathrm{P}=0.005, \mathrm{P}_{\mathrm{c}}=0.025\right)$. Furthermore, individuals

Table 3: The associations between the TIM-3 polymorphisms and clinical characteristics of breast cancer patients

\begin{tabular}{|c|c|c|c|c|c|c|c|c|}
\hline \multirow[t]{2}{*}{ Variables } & \multicolumn{4}{|c|}{ rs10053538 } & \multicolumn{4}{|c|}{ rs4704853 } \\
\hline & GG (\%) & $\begin{array}{c}\text { GT+TT } \\
(\%)\end{array}$ & $P *$ & $\begin{array}{c}\text { OR } \\
(95 \% \mathrm{CI})\end{array}$ & GG (\%) & $\begin{array}{c}\text { GA+AA } \\
(\%)\end{array}$ & $P *$ & $\begin{array}{c}\text { OR } \\
(95 \% \mathrm{CI})\end{array}$ \\
\hline \multicolumn{9}{|c|}{ Tumor size } \\
\hline$<2 \mathrm{~cm}$ & $53(28.3 \%)$ & $\begin{array}{c}134 \\
(71.7 \%)\end{array}$ & & $\begin{array}{c}1.00 \\
\text { (reference) }\end{array}$ & $\begin{array}{c}130 \\
(69.9 \%)\end{array}$ & $56(30.1 \%)$ & & $\begin{array}{c}1.00 \\
\text { (reference) }\end{array}$ \\
\hline$\geq 2 \mathrm{~cm}$ & $\begin{array}{c}120 \\
(32.3 \%)\end{array}$ & $\begin{array}{c}252 \\
(67.7 \%)\end{array}$ & 0.345 & $\begin{array}{c}0.83(0.57- \\
1.22)\end{array}$ & $\begin{array}{c}222 \\
(59.7 \%)\end{array}$ & $\begin{array}{c}150 \\
(40.3 \%)\end{array}$ & 0.018 & $\begin{array}{c}1.57(1.08- \\
2.28)\end{array}$ \\
\hline \multicolumn{9}{|l|}{$\begin{array}{l}\text { LN } \\
\text { metastasis }\end{array}$} \\
\hline Negative & $88(37.4 \%)$ & $\begin{array}{c}147 \\
(62.6 \%)\end{array}$ & & $\begin{array}{c}1.00 \\
\text { (reference) }\end{array}$ & $\begin{array}{c}151 \\
(64.0 \%)\end{array}$ & $85(36.0 \%)$ & & $\begin{array}{c}1.00 \\
\text { (reference) }\end{array}$ \\
\hline Positive & $85(26.2 \%)$ & $\begin{array}{c}239 \\
(73.8 \%)\end{array}$ & 0.005 & $\begin{array}{c}1.68(1.17- \\
2.42)\end{array}$ & $\begin{array}{c}201 \\
(62.4 \%)\end{array}$ & $\begin{array}{c}121 \\
(37.6 \%)\end{array}$ & 0.706 & $\begin{array}{c}1.07(0.76- \\
1.52)\end{array}$ \\
\hline \multicolumn{9}{|l|}{ ER } \\
\hline Negative & $74(31.5 \%)$ & $\begin{array}{c}161 \\
(68.5 \%)\end{array}$ & & $\begin{array}{c}1.00 \\
\text { (reference) }\end{array}$ & $\begin{array}{c}162 \\
(65.9 \%)\end{array}$ & $84(34.1 \%)$ & & $\begin{array}{c}1.00 \\
\text { (reference) }\end{array}$ \\
\hline Positive & $99(30.6 \%)$ & $\begin{array}{c}225 \\
(69.4 \%)\end{array}$ & 0.814 & $\begin{array}{c}1.05(0.73- \\
1.50)\end{array}$ & $\begin{array}{c}190 \\
(60.1 \%)\end{array}$ & $\begin{array}{c}122 \\
(39.1 \%)\end{array}$ & 0.228 & $\begin{array}{c}1.24(0.87- \\
1.75)\end{array}$ \\
\hline \multicolumn{9}{|l|}{ PR } \\
\hline Negative & $70(27.5 \%)$ & $\begin{array}{c}185 \\
(72.5 \%)\end{array}$ & & $\begin{array}{c}1.00 \\
\text { (reference) }\end{array}$ & $\begin{array}{c}168 \\
(66.4 \%)\end{array}$ & $85(33.6 \%)$ & & $\begin{array}{c}1.00 \\
\text { (reference) }\end{array}$ \\
\hline Positive & $\begin{array}{c}103 \\
(33.9 \%)\end{array}$ & $\begin{array}{c}201 \\
(66.1 \%)\end{array}$ & 0.101 & $\begin{array}{c}0.74(0.51- \\
1.06)\end{array}$ & $\begin{array}{c}184 \\
(60.3 \%)\end{array}$ & $\begin{array}{c}121 \\
(39.7 \%)\end{array}$ & 0.139 & $\begin{array}{c}1.30(0.92- \\
1.84)\end{array}$ \\
\hline \multicolumn{9}{|l|}{ HER-2 } \\
\hline Negative & $\begin{array}{c}118 \\
(30.3 \%)\end{array}$ & $\begin{array}{c}271 \\
(69.7 \%)\end{array}$ & & $\begin{array}{c}1.00 \\
\text { (reference) }\end{array}$ & $\begin{array}{c}233 \\
(52.2 \%)\end{array}$ & $\begin{array}{c}156 \\
(47.8 \%)\end{array}$ & & $\begin{array}{c}1.00 \\
\text { (reference) }\end{array}$ \\
\hline Positive & $55(32.4 \%)$ & $\begin{array}{c}115 \\
(67.6 \%)\end{array}$ & 0.635 & $\begin{array}{c}0.91(0.62- \\
1.34)\end{array}$ & $\begin{array}{c}119 \\
(88.2 \%)\end{array}$ & $50(11.8 \%)$ & 0.018 & $\begin{array}{c}0.63(0.43- \\
0.93)\end{array}$ \\
\hline
\end{tabular}

*Two-sided $x^{2}$ test for the distributions of genotype frequencies.

LN, Axillary lymph node; ER, Estrogen receptor; PR, Progesterone receptor; HER-2, human epidermal growth factor receptor 2 . 
harboring the rs4704853 polymorphism were more likely to have a larger tumor size $(\geq 2 \mathrm{~cm})(\mathrm{OR}=1.57,95 \% \mathrm{CI}$ $=1.08-2.28, \mathrm{P}=0.018)$; The significance was lost after Bonferroni correction $\left(\mathrm{P}_{\mathrm{c}}=0.09\right)$. However, no significant associations were detected between the rs10053538 or rs4704853 polymorphism and other clinical parameters of in patients with $\mathrm{BC}$.

\section{Stratified analysis of TIM-3 polymorphisms and breast cancer risk}

An age-stratified analysis of the effects of the TIM-3 rs10053538 and rs4704853 polymorphisms on the risk of $\mathrm{BC}$ is presented in Table 4. The results indicated that the rs4704853 GA + AA genotype was significantly more frequent among young participants $(\mathrm{OR}=1.49$, $95 \% \mathrm{CI}=1.05-2.11, \mathrm{P}=0.025)$. But no difference was found when Bonferroni correction was conducted. No positive results were observed for the rs 10053538 polymorphism.

\section{TIM-3 polymorphisms and TIM-3 protein expression}

Immunohistochemistry (IHC) was performed in tumor specimens to quantify and localize the expression of TIM-3 protein, From the Figure 1, the brown-stained part of the immunohistochemical analysis picture is TIM-3 protein. Microscopy images showed both nuclear and cytoplasm localization of TIM-3. We evaluated the association between rs 10053538 polymorphism and TIM3 protein expression levels in 100 breast cancer tissues by IHC assay. Of these tissues, the frequency distribution of the GG, GT and TT genotypes was 28, 57 and 15, respectively.
There was s significant difference in TIM-3 protein staining between the individuals with GT+TT and GG genotypes (average staining score: 3.7 versus 2.8 for GT+TT and GG genotypes, respectively, $\mathrm{P}=0.012$, Figure 1 ). Of the selected 100 tissues, the frequency distribution of the GG, GA and AA genotypes was 62, 37 and 1. Individuals carrying the GA+AA genotypes had no difference in TIM3 protein staining score compared with individuals with GG genotype (average staining score: 3.0 versus 3.4 for $\mathrm{GA}+\mathrm{AA}$ and $\mathrm{GG}$ genotypes, respectively, $\mathrm{P}=0.104$ ).

\section{DISCUSSION}

Most cancers result from interactions between genes and the environment [23]. Recent studies have identified environmental factors as major contributors to human cancers, for which the risks are strongly genetically influenced [24]. Individuals using longterm immunosuppressive medications (azathioprine, cyclophosphamide, and cyclosporine) or those with underlying immunologic abnormalities, such as an autoimmune disease or viral infection, are particularly at risk of malignancy [25]. Immune dysregulation plays a vital role in both initiation and progression of autoimmune disease [26]. The evidence indicates that immune suppression contributes to cancer progression. According to the immune surveillance theory, innate immunity is responsible for the early detection and elimination of malignant cells [27]. T cells and regulatory $\mathrm{CD}^{+} \mathrm{T}$ cells (Tregs) utilize a number of molecular pathways such as the expression of inhibitory molecules (PD-1) to suppress a variety of physiological and pathological immune responses [28, 29].

Table 4: Stratified analyses on association between TIM-3 polymorphisms and breast cancer risk

\begin{tabular}{|c|c|c|c|c|c|c|c|c|c|}
\hline \multicolumn{5}{|c|}{ rs10053538 } & \multicolumn{5}{|c|}{ rs4704853 } \\
\hline \multirow[t]{2}{*}{ Genotypes } & $\begin{array}{c}\text { Case } \\
(\mathrm{N}=559)\end{array}$ & $\begin{array}{c}\text { Control } \\
(\mathrm{N}=582)\end{array}$ & $P^{*}$ & $\begin{array}{c}\text { OR } \\
(95 \% \mathrm{CI})^{\dagger}\end{array}$ & Genotypes & $\begin{array}{c}\text { Case } \\
(\mathrm{N}=\mathbf{5 5 8})\end{array}$ & $\begin{array}{c}\text { Control } \\
(\mathbf{N}=\mathbf{5 8 0})\end{array}$ & $P^{*}$ & OR $(95 \% C I)^{\dagger}$ \\
\hline & N (\%) & $\mathbf{N}(\%)$ & & & & $\mathbf{N}(\%)$ & $\mathbf{N}(\%)$ & & \\
\hline Age $<49$ & & & & & Age $<49$ & & & & \\
\hline GG & $\begin{array}{c}89 \\
(32.0 \%)\end{array}$ & $\begin{array}{c}102 \\
(38.5 \%)\end{array}$ & 0.114 & $\begin{array}{c}1.00 \\
\text { (reference) }\end{array}$ & GG & $\begin{array}{c}170 \\
(61.8 \%)\end{array}$ & $\begin{array}{c}212 \\
(70.7 \%)\end{array}$ & 0.025 & $\begin{array}{c}1.00 \\
\text { (reference) }\end{array}$ \\
\hline GT+TT & $\begin{array}{c}189 \\
(68.0 \%)\end{array}$ & $\begin{array}{c}163 \\
(61.5 \%)\end{array}$ & & $\begin{array}{c}1.33(0.93- \\
1.89)\end{array}$ & $\mathbf{G A}+\mathbf{A A}$ & $\begin{array}{c}105 \\
(38.2 \%)\end{array}$ & $\begin{array}{c}88 \\
(29.3 \%)\end{array}$ & & $\begin{array}{c}1.49 \\
(1.05-2.11)\end{array}$ \\
\hline Age $\geq 49$ & & & & & Age $\geq 49$ & & & & \\
\hline GG & $\begin{array}{c}84 \\
(29.9 \%)\end{array}$ & $\begin{array}{c}119 \\
(37.5 \%)\end{array}$ & 0.049 & $\begin{array}{c}1.00 \\
\text { (reference) }\end{array}$ & GG & $\begin{array}{c}182 \\
(64.3 \%)\end{array}$ & $\begin{array}{c}190 \\
(67.9 \%)\end{array}$ & 0.374 & $\begin{array}{c}1.00 \\
\text { (reference) }\end{array}$ \\
\hline GT+TT & $\begin{array}{c}197 \\
(70.1 \%)\end{array}$ & $\begin{array}{c}198 \\
(62.5 \%)\end{array}$ & & $\begin{array}{c}1.41(1.00- \\
1.98)\end{array}$ & $\mathbf{G A}+\mathbf{A A}$ & $\begin{array}{c}101 \\
(35.7 \%)\end{array}$ & $\begin{array}{c}90 \\
(32.1 \%)\end{array}$ & & $\begin{array}{c}1.17 \\
(0.83-1.66)\end{array}$ \\
\hline
\end{tabular}

*Two-sided $x^{2}$ test for the distributions of genotype frequencies.

${ }^{\dagger}$ Adjusted for age and age at menarche. 
TIM-3, which is expressed by a subset of activated $\mathrm{CD}^{+} \mathrm{T}$ cells, has been identified as a negative regulator of immune tolerance in autoimmune and alloimmune responses [30]. TIM-3 is a transmembrane protein that selectively identifies Th1 cells not Th2 cells [31]. Carcinoembryonic antigen cell adhesion molecule 1 , another well-known molecule negatively regulating cellular activation, is co-expressed and forms a heterodimer with TIM-3 to regulate TIM-3-mediated tolerance and exhaustion $[32,33]$. Song et al. [34] observed that Tregs could affect the prognosis of acute lung injury by upregulating TIM-3 expression. TIM-3 expression was also observed on Tregs
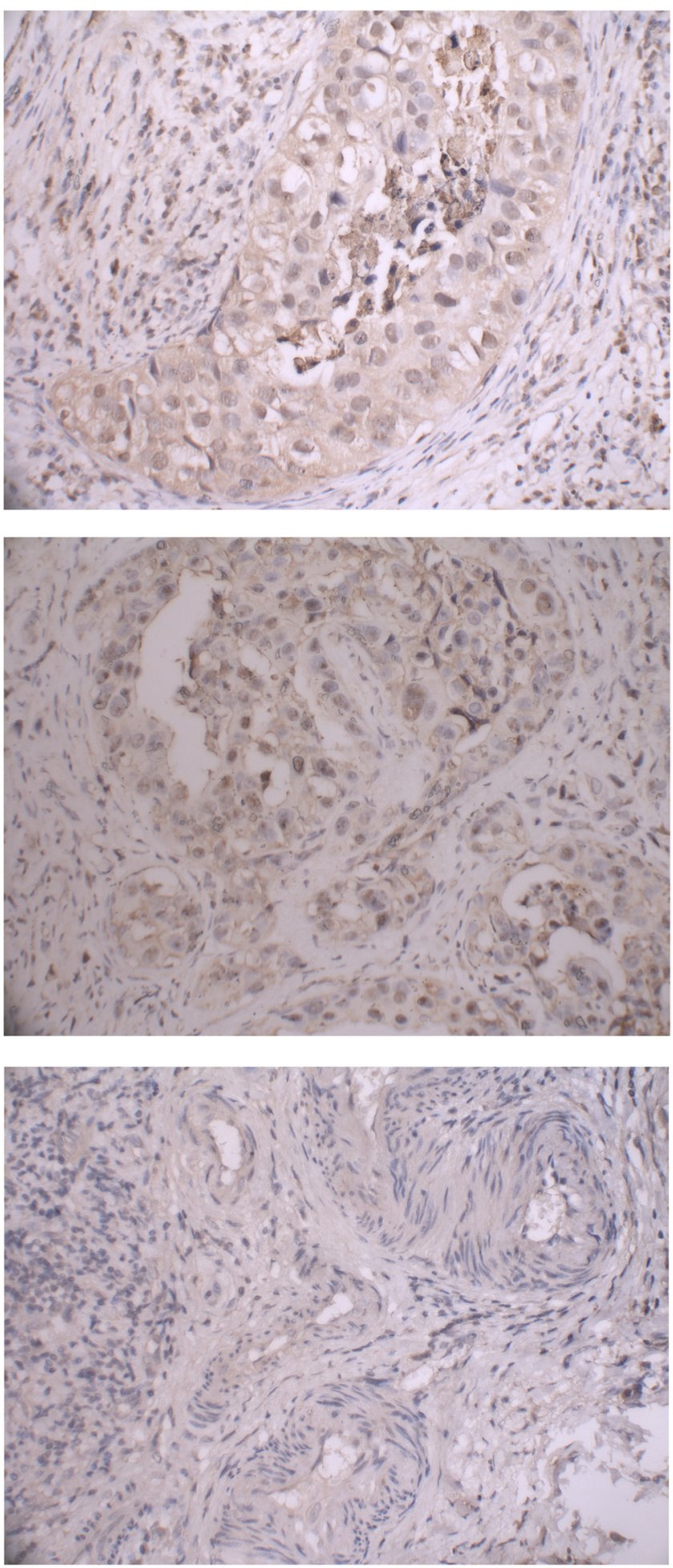

Figure 1: Immunohistochemical staining of TIM-3 protein in breast cancer tissues with rs10053538 GT, TT and GG genotypes. Representive images were obtained at $100 \times$ magnification. 
in the peripheral blood of chronically hepatitis $\mathrm{C}$ virusinfected individuals, and this protein was shown to affect cell proliferation and apoptosis during HIV infection by altering the balance between Tregs and effector T cells [35].

Previous studies have suggested associations between TIM-3 polymorphisms and some cancers and immune diseases. TIM-3 -574G/T and $+4259 \mathrm{~T} / \mathrm{G}$ were identified in patients with HIV-related non-Hodgkin lymphoma, nonsmall-cell lung cancer, and pancreatic cancer [20, 21, 36]. Rs11742259, rs10515746, rs35690726 and rs1036199 in TIM-3 were significantly associated with rheumatoid arthritis [37]. However, there were no previous reports of a relationship between TIM-3 polymorphisms and the risk of BC. In our study, we observed that the TIM-3 genotype variants rs 10053538 and rs4704853, but not rs1036199, were associated with an increased risk of BC. Heon et al. [38] found that IL-15 induced cell proliferation and interferon- $\gamma$ production by blocking TIM-3 activity. Blocking of TIM3 may be the therapeutic by enhancing the Th 1 cytokines response, down-regulating the $\mathrm{Th} 2$ cytokines response, and reducing $\mathrm{IgG} / \mathrm{IgE}$ production [39]. We also observed that the rs10053538 genotype variants were associated with a positive LN metastasis status. In immunohistochemical analysis, the results showed that individuals with rs10053538 GT+TT genotypes had a higher TIM-3 protein expression, which was in accordance with our result that TIM-3 rs10053538 GT+TT genotypes had a higher BC risk. It is probably because TIM-3 could negatively regulate the immune function of $\mathrm{T}$ cells and its higher protein expression level may suppress the immune response of $\mathrm{T}$ cells to tumors, which contributes to tumorigenesis. Our results demonstrated that TIM-3 rs 10053538 polymorphism might play a critical role in $\mathrm{BC}$ susceptibility.

Our study has some limitations. First, the sample size was inadequate for a stratified analysis and for analyzing associations in patients with mixed-type BC. Second, we did not investigate whether predisposing factors, including high-dose radiation exposure, alcohol consumption, and postmenopausal obesity, were associated with the risk of $\mathrm{BC}$ because of a lack of data from patients with $\mathrm{BC}$ and controls. In our future study, we will need to assess the effects of these factors on the risk of BC.

In conclusion, our case-control study indicates that rs10053538 GT+TT genetic variant in TIM-3 had positive effects on $\mathrm{BC}$ susceptibility and progression in a population of Chinese women. Further functional studies and large population-based prospective studies will be required to further elucidate the influence of TIM-3 polymorphisms on $\mathrm{BC}$.

\section{MATERIALS AND METHODS}

\section{Ethics statement}

The study was approved by the Institutional Review Board of Xi'an Jiaotong University (Xi'an, China). Written informed consent was obtained from all participants involved in the study at the time of recruitment.

\section{Study participants}

This case-control study included 560 patients with BC and 583 cancer-free controls, as we described previously [40, 41]. All participants were recruited without the restrictions of age. All patients were diagnosed with pathologically confirmed sporadic BC between January 2013 and October 2014 at the Second Affiliated Hospital of Xi'an Jiaotong University, China. Patients who received preoperative chemotherapy or radiotherapy or had a previous history of other types of cancer were excluded from the study. The controls were randomly selected from among healthy volunteers who underwent annual physical examinations in the hospital outpatient department and had no previous history of cancer. Controls were frequency matched to the patients according to age ( \pm 5 years). All methods were carried out in accordance with the approved guideline. All participants who provided written informed consent were interviewed to obtain detailed information about selfadministration. After the interview, a venous blood sample (approximately $2 \mathrm{~mL}$ ) was collected from each participant.

\section{DNA extraction}

Whole blood samples were collected into EDTAcoated tubes and stored at $-80^{\circ} \mathrm{C}$ after centrifugation until further analysis. Genomic DNA was extracted from whole blood using a standard phenol-chloroform extraction method. DNA concentrations were measured via spectrometry (DU530 UV/VIS spectrophotometer; Beckman Instruments, Fullerton, CA, USA).

\section{SNP selection and genotyping}

For our study, we selected candidate SNPs in TIM according to HapMap data from a Chinese population. To achieve a power of at least $50 \%$, only SNPs with a minor allele frequency (MAF) $>0.01$ was included. MassARRAY Assay Design 3.0 Software (Sequenom Laboratories, San Diego, CA, USA) was used to design a multiplexed SNP MassEXTEND assay. Finally, a total of three SNPs in TIM were included in this study. Genotyping of TIM3 SNPs was performed with Sequenom MassARRAY RS1000, according to the manufacturer's instructions. The corresponding primers used for each SNP in this study are listed in Table 5. Sequenom Typer 3.0 Software was used for the data analyses.

\section{Immunohistochemistry (IHC)}

From the patient group, we selected 100 tissue specimens from October 2013 to October 2014 and performed immunohistochemical analysis of paraffin sections embedded breast cancer tissues. Firstly, 
Table 5: Primers used for this study

\begin{tabular}{lccc}
\hline SNP_ID & 1st-PCRP & 2nd-PCRP & UEP_SEQ \\
\hline $\mathbf{r s 1 0 0 5 3 5 3 8}$ & ACGTTGGATGCGGTGGCTATGCCTGTAAAC & ACGTTGGATGCATGTTGGTCAGGCTGTTCT & AGGCGATCCACCCGCCTC \\
$\mathbf{r s 4 7 0 4 8 5 3}$ & ACGTTGGATGTCATGCATACAAGGTGCCCC & ACGTTGGATGGGCTGGAACTCAACACTTTC & ATGGCCAAAGCCTCT \\
$\mathbf{r s 1 0 3 6 1 9 9}$ & ACGTTGGATGCCTGGTGGTAAGCATCCTTG & ACGTTGGATGCTGACATTAGCCAAGGTCAC & gCCCCTGCACCGACTC \\
\hline
\end{tabular}

parafin sections were roasted at $60^{\circ} \mathrm{C}$ for two hour, then deparaffinized and rehydrated through dimethylbenzene for $30 \mathrm{~min}$ and a descending alcohol series for $5 \mathrm{~min}$, respectively. Endogenous peroxidase activity was blocked with $3 \%$ hydrogen peroxide for 20 minutes at room temperature. Then wash the slides with running water for $10 \mathrm{~min}$ before being exposed to the antigen retrieval system $(0.01 \mathrm{M}$ sodium citrate, $0.05 \%$ Tween $20, \mathrm{pH} 6.0)$ in electromagnetic oven for $10 \mathrm{~min}$. Nonspecific stainings were blocked with closed serum for $15 \mathrm{~min}$ at room temperature. Then dump the excess liquid and dropped a primary antibody (1:100, ab185703, abcam, America) for incubation at $4{ }^{\circ} \mathrm{C}$ overnight. After washing the slides with $0.01 \mathrm{~mol} / \mathrm{L}$ phosphate buffer saline (PBS) for 3 times for $5 \mathrm{~min}$ each time, incubated the slides with rabbit antibody (1:50, Boster, China) 30 minutes at $37^{\circ} \mathrm{C}$. Then rinsed the slides in PBS 3 times for $5 \mathrm{~min}$ each time and stained the slides with DAB peroxidase substrate kit (Gene Tech, China). The slides were washed by running water for 10 min and conterstained with hematoxylin. The tissue sections then were observed under a microscope, after being dehydrated, cleared and finally mounted with neutral gum.

\section{Evaluation of the IHC variable}

The TIM-3 expression was evaluated by two independent pathologists in a blind fashion. The stained sections were screened under low power $(\times 100$-fold magnification) to identify representative fields. TIM-3 positive cells were then countered under high power $(\times 400$ fold magnification) in 8 fields of vision and got the average. The staining results were calculated by multiplying the intensity and percentage of positive cells, and categorized as follows: no staining $=0$, weak staining $=1$, moderate staining $=2$, and strong staining $=3$. The percentage of the stained cells was categorized as follows: $\leq 5 \%=0,>5 \%$ but $<25 \%$ $=1,>25 \%$ but $<50 \%=2$, and $>50 \%=3$. Then the staining results were calculated with semi-quantitative analysis $($ HSCORE system $=$ stain intensity $\times$ the percentage of the stained cells). The score of $0-1$ was consider as negative outcome (-), 2-3 weak positive $(+), 4-6$ moderate positive $(++),>6$ strong positive $(+++)$.

\section{Statistical analysis}

The statistical power of the case-control study was calculated using QUANTO software 1.2.4 (University of Southern California, Los Angeles, CA, USA).HardyWeinberg Equilibrium (HWE) was tested for each SNP before the analysis. The Student $t$-test or the $\chi^{2}$ test was used to compare differences in the distributions of demographic characteristics and selected variables, as well as the genotype frequency distributions between patients and controls. We conducted a case-control study for all of the subjects, and then the patients were stratified by clinical characteristics and age under the multivariate logistic regression model. Odds ratios (ORs) and 95\% confidence intervals (CIs) were used to assessed the degree of association between the TIM-3 rs 10053538, rs4704853, and rs 1036199 polymorphisms and BC. All statistical analyses were performed using SPSS 18.0 software for Windows (SPSS Inc., Chicago, IL, USA). Differences were considered statistically significant at a $\mathrm{P}_{\mathrm{c}}<0.05$ after the $\mathrm{p}$ value was corrected by Bonferroni correction, and all statistical tests were two-sided.

\section{ACKNOWLEDGMENTS}

This study was supported by National Natural Science Foundation, China (No. 81471670); China Postdoctoral Science Foundation (No. 2014M560791; 2015T81037); the Science and Technology Plan of Innovation Project, Shaanxi province, China (No. 2015KTCL03-06); the Fundamental Research Funds for the Central Universities, China (No. 2014qngz04); and specialized Research Fund of the Second Affiliated Hospital of Xi'an Jiaotong University, China [RC (GG) 201203]. Thanks for the language editing by Editage.

\section{COMPETING INTERESTS}

The authors have declared that no competing interest exists.

\section{REFERENCES}

1. Pesec M and Sherertz T. Global health from a cancer care perspective. Future Oncol. 2015; 11:2235-2245.

2. Brisken $\mathrm{C}$, Hess $\mathrm{K}$ and Jeitziner R. Progesterone and Overlooked Endocrine Pathways in Breast Cancer Pathogenesis. Endocrinology. 2015:en20151392. 
3. Fitzmaurice C, Dicker D, Pain A, Hamavid H, MoradiLakeh M, MacIntyre MF, Allen C, Hansen G, Woodbrook R, Wolfe C, Hamadeh RR, Moore A, Werdecker A, et al. The Global Burden of Cancer 2013. JAMA Oncol. 2015; 1:505-527.

4. Kochan DZ and Kovalchuk O. Circadian disruption and breast cancer: An epigenetic link? Oncotarget. 2015; 6:16866-16882. doi: 10.18632/oncotarget.4343.

5. Tryggvadottir L, Sigvaldason H, Olafsdottir GH, Jonasson JG, Jonsson T, Tulinius H and Eyfjord JE. Population-based study of changing breast cancer risk in Icelandic BRCA2 mutation carriers, 1920-2000. J Natl Cancer Inst. 2006; 98:116-122.

6. King MC and Motulsky AG. Human genetics. Mapping human history. Science. 2002; 298:2342-2343.

7. Evans DG, Shenton A, Woodward E, Lalloo F, Howell A and Maher ER. Penetrance estimates for BRCA1 and BRCA2 based on genetic testing in a Clinical Cancer Genetics service setting: risks of breast/ovarian cancer quoted should reflect the cancer burden in the family. BMC Cancer. 2008; 8:155.

8. Deng X, Zhao $\mathrm{Y}$ and Wang B. miR-519d-mediated downregulation of STAT3 suppresses breast cancer progression. Oncol Rep. 2015.

9. Lin X, Chen L, Yao Y, Zhao R, Cui X, Chen J, Hou K, Zhang M, Su F, Chen J and Song E. CCL18-mediated downregulation of miR98 and miR27b promotes breast cancer metastasis. Oncotarget. 2015. doi: 10.18632/oncotarget.4107.

10. Zhang L and Long X. Association of three SNPs in TOX3 and breast cancer risk: Evidence from 97275 cases and 128686 controls. Sci Rep. 2015; 5:12773.

11. Freeman GJ, Casasnovas JM, Umetsu DT and DeKruyff RH. TIM genes: a family of cell surface phosphatidylserine receptors that regulate innate and adaptive immunity. Immunol Rev. 2010; 235:172-189.

12. Wang M, Ji B, Wang J, Cheng X, Zhou Q, Zhou J, Cao $\mathrm{C}$ and Guo Q. Tim-3 polymorphism downregulates gene expression and is involved in the susceptibility to ankylosing spondylitis. DNA Cell Biol. 2014; 33:723-728.

13. Chen J, Sun G, Chen F, Fang Y, Gates MH and Yang S. T-cell immunoglobulin domain and mucin domain 3 polymorphism affects cytokine expression in different cells and is associated with increased susceptibility to knee osteoarthritis. Gene. 2015; 566:32-36.

14. Golden-Mason L, Waasdorp Hurtado CE, Cheng L and Rosen HR. Hepatitis C viral infection is associated with activated cytolytic natural killer cells expressing high levels of T cell immunoglobulin- and mucin-domain-containing molecule-3. Clin Immunol. 2015; 158:114-125.

15. Zhu C, Anderson AC, Schubart A, Xiong H, Imitola J, Khoury SJ, Zheng XX, Strom TB and Kuchroo VK. The Tim-3 ligand galectin-9 negatively regulates T helper type 1 immunity. Nat Immunol. 2005; 6:1245-1252.

16. Sehrawat S, Suryawanshi A, Hirashima $M$ and Rouse BT. Role of Tim-3/galectin-9 inhibitory interaction in viral-induced immunopathology: shifting the balance toward regulators. J Immunol. 2009; 182:3191-3201.

17. Qiu MK, Wang SC, Dai YX, Wang SQ, Ou JM and Quan ZW. PD-1 and Tim-3 Pathways Regulate CD8+ T Cells Function in Atherosclerosis. PLoS One. 2015; 10:e0128523.

18. Severson JJ, Serracino HS, Mateescu V, Raeburn CD, McIntyre RC, Jr., Sams SB, Haugen BR and French JD. PD-1+Tim-3+ CD8+ T Lymphocytes Display Varied Degrees of Functional Exhaustion in Patients with Regionally Metastatic Differentiated Thyroid Cancer. Cancer Immunol Res. 2015; 3:620-630.

19. Zhang ZN, Zhu ML, Chen YH, Fu YJ, Zhang TW, Jiang YJ, Chu ZX and Shang H. Elevation of Tim-3 and PD-1 expression on $\mathrm{T}$ cells appears early in HIV infection, and differential Tim-3 and PD-1 expression patterns can be induced by common gamma -chain cytokines. Biomed Res Int. 2015; 2015:916936.

20. Bai J, Li X, Tong D, Shi W, Song H and Li Q. T-cell immunoglobulin- and mucin-domain-containing molecule 3 gene polymorphisms and prognosis of non-small-cell lung cancer. Tumour Biol. 2013; 34:805-809.

21. Song H, Ma S, Cha Z, Chen L, Tong D, Ma L, Song W and Bai J. T-cell immunoglobulin- and mucin-domaincontaining molecule 3 genetic variants and HIV+ nonHodgkin lymphomas. Inflammation. 2013; 36:793-799.

22. Li S, Ren Y, Peng D, Yuan Z, Shan S, Sun H, Yan X, Xiao H, Li G and Song H. TIM-3 Genetic Variations Affect Susceptibility to Osteoarthritis by Interfering with Interferon Gamma in CD4+ T Cells. Inflammation. 2015.

23. Perera FP. Environment and cancer: who are susceptible? Science. 1997; 278:1068-1073.

24. Perera FP. Molecular epidemiology: insights into cancer susceptibility, risk assessment, and prevention. J Natl Cancer Inst. 1996; 88:496-509.

25. Penn I. Posttransplant malignancies. Transplant Proc. 1999; 31:1260-1262.

26. Chruscinski A, Sadozai H, Rojas-Luengas V, Bartczak A, Khattar R, Selzner N and Levy GA. Role of Regulatory T Cells (Treg) and the Treg Effector Molecule Fibrinogenlike Protein 2 in Alloimmunity and Autoimmunity. Rambam Maimonides Med J. 2015; 6.

27. Whiteside TL. Immune suppression in cancer: effects on immune cells, mechanisms and future therapeutic intervention. Semin Cancer Biol. 2006; 16:3-15.

28. Gavin MA, Rasmussen JP, Fontenot JD, Vasta V, Manganiello VC, Beavo JA and Rudensky AY. Foxp3dependent programme of regulatory T-cell differentiation. Nature. 2007; 445:771-775.

29. Lapierre $P$ and Lamarre A. Regulatory $T$ Cells in Autoimmune and Viral Chronic Hepatitis. J Immunol Res. 2015; 2015:479703.

30. Gautron AS, Dominguez-Villar M, de Marcken M and Hafler DA. Enhanced suppressor function of TIM-3+ FoxP3+ regulatory T cells. Eur J Immunol. 2014; 44:2703-2711. 
31. Sanchez-Fueyo A, Tian J, Picarella D, Domenig C, Zheng XX, Sabatos CA, Manlongat N, Bender O, Kamradt T, Kuchroo VK, Gutierrez-Ramos JC, Coyle AJ and Strom TB. Tim-3 inhibits $\mathrm{T}$ helper type 1-mediated auto- and alloimmune responses and promotes immunological tolerance. Nat Immunol. 2003; 4:1093-1101.

32. Iijima $H$, Neurath MF, Nagaishi $T$, Glickman JN, Nieuwenhuis EE, Nakajima A, Chen D, Fuss IJ, Utku N, Lewicki DN, Becker C, Gallagher TM, Holmes KV and Blumberg RS. Specific regulation of $\mathrm{T}$ helper cell 1-mediated murine colitis by CEACAM1. J Exp Med. 2004; 199:471-482.

33. Huang YH, Zhu C, Kondo Y, Anderson AC, Gandhi A, Russell A, Dougan SK, Petersen BS, Melum E, Pertel T, Clayton KL, Raab M, Chen Q, et al. CEACAM1 regulates TIM-3-mediated tolerance and exhaustion. Nature. 2015; 517:386-390.

34. Song H, Zhou Y, Li G and Bai J. Regulatory T cells contribute to the recovery of acute lung injury by upregulating Tim-3. Inflammation. 2015; 38:1267-1272.

35. Moorman JP, Wang JM, Zhang Y, Ji XJ, Ma CJ, Wu XY, Jia ZS, Wang KS and Yao ZQ. Tim-3 pathway controls regulatory and effector $\mathrm{T}$ cell balance during hepatitis $\mathrm{C}$ virus infection. J Immunol. 2012; 189:755-766.

36. Tong D, Zhou Y, Chen W, Deng Y, Li L, Jia Z and Qi D. $\mathrm{T}$ cell immunoglobulin- and mucin-domain-containing molecule 3 gene polymorphisms and susceptibility to pancreatic cancer. Mol Biol Rep. 2012; 39:9941-9946.
37. Song YW, Im CH, Park JH, Lee YJ, Lee EY, Lee EB and Park K. T-cell immunoglobulin and mucin domain 3 genetic polymorphisms are associated with rheumatoid arthritis independent of a shared epitope status. Hum Immunol. 2011; 72:652-655.

38. Heon EK, Wulan H, Macdonald LP, Malek AO, Braunstein GH, Eaves CG, Schattner MD, Allen PM, Alexander MO, Hawkins CA, McGovern DW, Freeman RL, et al. IL-15 induces strong but short-lived tumor-infiltrating CD8 T cell responses through the regulation of Tim- 3 in breast cancer. Biochem Biophys Res Commun. 2015; 464:360-366.

39. Tang F, Wang F, An L and Wang X. Upregulation of Tim-3 on CD4(+) T cells is associated with Th1/Th2 imbalance in patients with allergic asthma. Int J Clin Exp Med. 2015; 8:3809-3816.

40. Dai ZJ, Liu XH, Kang HF, Wang XJ, Jin TB, Zhang SQ, Feng T, Ma XB, Wang M, Feng YJ, Liu K, Xu P and Guan HT. Genetic Variation in Metastasis-Associated in Colon Cancer-1 and the Risk of Breast Cancer Among the Chinese Han Population: A STROBE-Compliant Observational Study. Medicine (Baltimore). 2016; 95:e2801.

41. Dai ZJ, Liu XH, Ma YF, Kang HF, Jin TB, Dai ZM, Guan HT, Wang M, Liu K, Dai C, Yang XW and Wang XJ. Association Between Single Nucleotide Polymorphisms in DNA Polymerase Kappa Gene and Breast Cancer Risk in Chinese Han Population: A STROBE-Compliant Observational Study. Medicine (Baltimore). 2016; 95:e2466. 